INTERNATIONAL JOURNAL OF

MULTIDISCIPLINARY STUDIES ON MANAGEMENT, BUSINESS, AND ECONOMY

\title{
Executive Mission of Cultural Hand Crafts in Upper Egypt: Advertising and
}

\section{Promotion}

\section{Badawi Ismail}

Professor, Faculty of Archaeology, Luxor University, Luxor, Egypt

\begin{abstract}
The Paper aims at determining the role of the media in highlighting the role of artisan artist and presenting his issues by presenting his works. Also to discuss the role of the media in helping the taste of research, knowledge and visual culture and the role of the media in increasing the popularity and mass density which is one of the most important elements of the success of the exhibitions and the necessity of accompanying the exhibitions.

The Research recommended the establishment of media programs based on a series of steps to promote and publicize the products. The media plans include artistic art issues and the need to increase media coverage programs in exhibitions, salons and trade fairs. U $r$ t seminars need to choose the optimal means for advertising and product advertising and requirements and to develop the mechanisms for the design of advertisement according to the promotional mix, which is one of the components of the marketing mix.
\end{abstract}

Keywords

Hand Crafts-Seminars-Media-Communication-Culture.

\section{OPERATIONAL ACTIVITIES:}

\section{- Focus Groups:}

- The implementation of five focus groups in which the experts of advertising and media, specialists in traditional crafts, traditional industries and marketing experts participated.

- The participants discussed the lack of communication and media role as the basis of culture and the lack of media programs that deal with the heritage and the lack of media interest in the definition of the art of art and heritage. Heritage and highlight its importance to development issues.

- The focus groups focused on the absence of awareness programs to educate the consumer about traditional and heritage industries and not to take any cultural media measures to directly influence the culture of individuals and groups of society, including the creation, production, dissemination and broadcasting of creative activities, products and services. The focus groups noted the lack of propaganda activities Audience for Creative Products Focus groups have recommended a range of measures, including restoration of traditional crafts and traditional products, through the promotion of the image of the traditional Egyptian manufacturer, in the targeted markets through the press, press articles and news and events The production of films and booklets on the heritage products of each region - To take the necessary measures to implement information programs aimed at preserving the cultural

\footnotetext{
*Corresponding author: info@uop.edu.jo
} 
heritage of heritage and handicrafts, encouraging innovation and organizing programs to increase awareness of the tools and characteristics of heritage as one of the attractions of tourism and increase the role and responsibility of social media tools in the growth of the economy and as a tool for change and education.

- To highlight the creativity in heritage industries and to allocate areas in programs, newspapers and daily newspapers and to increase the cultural and artistic media to promote traditional and creative industries and increase the role of media in art forums and art activities and events of heritage exhibitions and linking media policy to the plan of promotion and promotion in satellite programs And the role of the media in educating the consumer culture of acquisition and demand for exhibitions and intensify media coverage in the organization of exhibitions to identify artisans and artisan art.

\section{- Seminars:}

The project organized five seminars to discuss issues of advertising, advertising and promotion of traditional and heritage industries in the southern governorates and with experts in the capital in Cairo.

\section{- Target Groups:}

- Local producers.

- The media.

- NGOs.

- Stakeholders.

\section{- Objectives of the Seminars:}

- The seminars aim at determining the role of the media in highlighting the role of artisan artist and presenting his issues by presenting his works.

- The seminars discussed the role of the media in helping the taste of research, knowledge and visual culture and the role of the media in increasing the popularity and mass density which is one of the most important elements of the success of the exhibitions and the necessity of accompanying the exhibitions. 
- The seminars recommended the establishment of media programs based on a series of steps to promote and publicize the products. The media plans include artistic art issues and the need to increase media coverage programs in exhibitions, salons and trade fairs. Urt seminars need to choose the optimal means for advertising and product advertising and requirements and to develop the mechanisms for the design of advertisement according to the promotional mix, which is one of the components of the marketing mix.

\section{- Field Survey:}

A specialized research team has been appointed to carry out the field survey on the issues of advertising, publicity and difficulties of promotion of traditional and heritage industries. The team included researchers in the media and researchers with field experience.

\section{The main methods of field survey included:}

- Individual interviews.

- $\quad$ Conduct a survey of media activities.

- $\quad$ Review media activities.

- Holding meetings with the main bodies entrusted with publicity and promotion and with the artisans in the south to know and evaluate the media coverage in order to exchange experiences and expertise and find alternatives and solutions to the problems that hinder the development of the handicrafts sector and traditional industries.

\section{- Questionnaire:}

A questionnaire was prepared for individuals, NGOs, local and media producers to identify the objectives, activities, challenges and measures required, to measure challenges and to identify necessary and required measures.

\section{- Workshops:}

Workshops were held in the governorates of the South. The participants and 
participants in the workshops were selected on the basis of geographical location and based on experience in the field of advertising and advertising. The workshops sought to activate participation and expertise in the field of promotion, advertising and advertising.

Workshops reached a common understanding of the issues of promotion and advertising facing the artisans of traditional and heritage products were highlighted on the issues facing the expansion of vogue traditional and heritage industries base and or $\mathrm{r} t$ workshops to the need to rely on advertising and media programs to encourage consumers to acquire traditional products by National television channels and satellite channels through intriguing programs Consumer and attracted to Egyptian products.

The workshops recommended the need to activate many activities and information programs to increase awareness of the protection and continuity of heritage -The need to support and mobilize media efforts to revive heritage and cultural heritage and to promote and promote the products of traditional and tourism industry through the establishment of mobile exhibitions for products of traditional industries and heritage crafts Organize awareness campaigns, educate, promote and provide a broad media base to promote the marketing of products.

\section{EXECUTIVE MISSION: MARKETING:}

\section{- Operational Activities:}

\section{- Focal Groups:}

Five focus groups were held in the governorates of the South and Cairo, which included a number of marketing experts, government officials and civil society officials to discuss the issues related to marketing and promotion in order to expand the base of traditional crafts and traditional industries and keep pace with the needs and variables of internal and external market.

\section{The Results of the Focus Group Work Monitored the Following Challenges:}

- And the absence of a clear strategic policy to promote traditional handicraft products and traditional industries at the national and international levels.

- And the absence of a marketing policy based on efficiency, transparency and diversification 
of markets at the internal level.

- Absence of the role of advertising programs and advertising programs and to encourage the consumer to acquire traditional and heritage products.

- Absence of programs that help entrepreneurs identify markets and target consumer behavior.

- Absence of the governmental role in helping to continue organizing exhibitions and diversification to open the door to the largest number of local producers in urban, rural and rural areas to highlight their products and introduce them.

- Failure to take measures and measures that will protect national products to keep up with and maintain sustainability, continuity and responsiveness to the requirements and tastes of the consumer.

- The absence of studies for the target markets and the absence of field studies for the markets, including the search for channels of distribution and direct recovery through exhibitions.

- Absence of surveys to stimulate marketing programs and foreign markets to achieve a high level of exports.

- Absence of studies of the needs of consumer strata and consumer markets.

- Lack of planning for consumer incentive programs in local and foreign markets according to trends, tastes and purchasing motives.

- Lack of modern scientific studies in the field of marketing and lack of interest in marketing research in the field of market study and methods of transport and distribution, packaging and consumer tastes, which limits the ability of these industries to market their products.

- The absence of a regulatory framework for the marketing process is taken as a base to help implement the rehabilitation programs of traditional and heritage industries.

\section{- Survey:}

A survey was performed to better understand the difficulties of marketing, promotion and targeted survey of local producers and m Soukaan.

\section{The survey was based on:}

- The method of personal interview with local producers, artisans and marketers. 
- Comprehensive forms of detailed information on marketing and promotion in terms of difficulties, gaps, threats and necessary measures.

- A questionnaire covering the marketing challenges and difficulties was distributed to local producers and target marketers.

The survey concluded the urgent need for a strategic plan to stimulate competitive advantage, provide support for marketing and promote the promotion of traditional industries and heritage crafts.

- Identify marketing challenges that can hinder the progress of any production project.

- Lack and absence of programs to identify artisans and local producers with market developments.

- Lack of skills in how to deal with the challenges of the age and competition in foreign markets and limited marketing potential provided by the internal market.

- The entry of similar and competitive traditional products at reduced prices led to the recession of many traditional and local industries and the disappearance of some of them.

- Challenges related to low demand for some traditional products due to quality, lack of diversification and innovation.

- Challenges related to the lack of advertising programs in the promotion and marketing of products and the absence of active marketing support needed by the heritage sector.

- Challenges related to the absence of promotional campaigns for Egyptian products for consumers to encourage them to buy Egyptian products and contribute to the promotion of local products.

- Lack of detailed marketing studies for the consumer and the market.

- There are many brokers in the field of marketing of heritage and creative products.

- Challenges to the lack of quality signs and to the promotion and promotion of products.

- Challenges related to lack of Walt Will financial support I have the product of the reasons that hinder the production and development and innovation processes in the traditional heritage and tourism industries.

\section{- Workshops:}


Five workshops were held in the governorates of the south and Cairo to discuss the difficulties of local producers' access to the markets in terms of absence of associations to sponsor local producers in marketing and lack of exhibitions. Necessary to market products both locally and internationally. The current exhibitions are not suitable for the quantities of products and the huge number of craftsmen in Egypt.

\section{- Targeted Groups:}

- Local producers.

- Craftsmen.

- Marketers.

- Officials of the Ministry of Commerce, Industry, Social Affairs and concerned governorates.

\section{The workshops discussed the current status of marketing in Egypt:}

The diagnosis of the current situation of difficulties and obstacles in the field of marketing heritage and traditional products from the absence of supporting services to help market knowledge and the behavior of consumers and target markets and lack of information programs that help to highlight the specifics and referral of local products from traditional and traditional industries at the local, national and international levels.

- The lack of skills in the quality of the product and the revival of the marketing of traditional and traditional products and the existence of a large gap between the product and the merchant and a large gap between the foreign importer and exporter and the number of intermediaries in the field of marketing.Marketing Awareness in the Egyptian Commercial Center The workshops concluded that there are obstacles in the lack of skills in keeping up with the tastes of the heritage industry owners and the inappropriate and adapting designs of these products according to the tastes and the lack of regular marketing outlets to identify the local and external consumers with heritage and traditional products and the narrow local market for those products in Egypt and lack of efficiency, marketing of small businesses and micro to the lack of specialists with those experiences and take the necessary measures to enable the artisans to develop their products and reach out to consumers with high quality so as not to back down in front of the flow of Alternative or counterfeit goods 
and to take the necessary skills development for artisans measures to identify the nature and tastes of consumers and identify alternative commodities and competition in terms of price, quality and quantity.

\section{EXECUTIVE TASK: FUNDING:}

\section{- Activities:}

\section{- Groups:}

Three focus groups were held among banks experts, craftsmen and local marketers to examine and assess the current situation and the status quo to support small and micro enterprises, producers and discussed the focus groups and financing difficulties faced by projects of the narrow and limited financial possibilities,problems and Alassa financing is now facing the growth of traditional crafts sector projects and traditional industries Of tightness and limited financial resources available.

Some commercial banks hesitated to give these industries short- or long-term loans The high interest rate that weighs the budgets of those industries, whichlimits the ability of these industries to expand their productive capacity.

The low credit duration and its adequacy as the appropriate financing for these industries is considered unsuitable for their financing needs.

\section{- Survey:}

The objective of the survey included identifying images of support and funding providers.

\section{The survey covered the following issues:}

- Target customers.

- Type of development services.

- Challenges to financing.

- Difficulties related to the provision of project development services.

- Steps to improve the working environment. 
- Studying bank financing practices.

- The adequacy of supporting services for small and micro enterprises.

\section{- Survey:}

A survey was conducted to identify banks' practices in project finance.

\section{The survey was based on:}

1) Form BI (Questionnaire) It was distributed to banks.

\section{- The questionnaire was designed in three sections:}

- The practice of financial institutions

- $\quad$ Practice of beneficiary projects.

- $\quad$ Evaluation of practices.

\section{Targeted Groups:}

- $\quad$ Banks offering financing.

- $\quad$ Small Business Owners.

- $\quad$ Craftsmen and local producers.

\section{- Interviews:}

Bankers were interviewed with the aim of obtaining complementary information from the experiences of banks, bankers, artisans and entrepreneurs to identify the challenges and funding constraints facing projects.

\section{- Case studies:}

Conduct a case study of the experience of business incubators and assess the current 
situation of women's participation in business incubators in a business incubator and study the obstacles facing entrepreneurship.

- Conduct a study to examine the current status of entrepreneurs and entrepreneurs by examining samples of support types targeted at entrepreneurs.

- Conduct a survey of projects and financing practices for projects directed at women and craftsmen to enable them economically to identify the needs of rural communities in Upper Egypt and analyze the economic projects of craftsmen and women in the regions The poorest in Upper Egypt.

- Focus the spotlight on small projects that are popular among artisans and women in order to expand their programs, improve their attractiveness and mitigate their negative effects.

Five workshops were held:

\section{1- Case Study of Women Entrepreneurship:}

The study was conducted in terms of cultural and social barriers and access to finance and lack of knowledge and skills to work the complex registration process and procedures and obtain licenses and the difficulty of access to markets and local constraints that limit women 's choice for her career, which leads to lower ratesof participation of women Weak entrepreneurial culture and access to distant markets.

2- A study of funding issues in terms of difficulty of access and access to finance and lack of a presence and multiple guarantees of loans and the lack of availability of MFIs and issues of inability to access funding and lack of skills in financial management and accounting and marketing and lack of knowledge of legal procedures and organization of work, which adversely affect the continuity of growth and the ability to continue.

3- Provide entrepreneurs with information on various types of funding and sources - Help identify sources of funding that transform ideas into actual projects and support loan applications.

4- Providing information and assistance in identifying sources of funding - Definition of financing loan - Assistance in preparing the proposal for financing and accompanying banks The need to expand banking services for rural and marginalized sectors of the population. 


\section{Workshops:}

Five workshops made in the presence of banks, NGOs representatives, artisans and local producers in order to better understand financing practices and studyingthe practice of financing pain Grate in the definition of imposing funding and discussed the workshop methods to help craftsmen and women in identifying appropriate sources of funding to turn their ideas into projects.

The workshops reached recommendations and measures to increase the amount of bank loans granted to local producers - - Reduce the interest rate on traditional crafts and treat them as small projects by $5 \%$. - Recommend the expansion of the system of microsyndicated bank loans and facilitate the procedures for obtaining bank loans in terms of canceling the request for personal guarantees and expanding the promotion of the work of NGOs in the field of micro- credit to serve as cells to mediate between manufacturers and banks through On loans through an intermediary.

- Encouraging associations to carry out the roles of identifying and advertising products, facilitating access to bank loans and enhancing networks to improve women's access to information and exchange of experiences.

- Increase the opportunities for communication between business leaders to help exchange experiences and information.

- And promote business relationships.

- Provide spaces for communication and exchange of ideas, which encourages innovation and give a sense of support and confidence, which will enable them to prepare better and achieve success.

- Helps connect business leaders with funding sources.

- Provide business leaders with information on various types and sources of funding.

- Help identify sources of funding that transform ideas into actual projects - Support in loan applications.

- Definition of funding opportunities.

- Assist in the preparation of the proposal and the accompanying funding data banks.

Experience of business incubators in heritage craft projects (good incubator).

The idea of establishing incubators is to provide a supportive environment that 
enables entrepreneurs to work on developing the idea of their projects, planning their business development, training and guidance, and providing a safe and welcoming space to receive the moral support needed to improve managerial and entrepreneurial capacities. Support incubators to develop their businesses by allowing start-up projects to stay in the incubator.

And take promotional measures for incubators to reach women and hold workshops to promote the role of women in entrepreneurial projects.

\section{Incubators aim to:}

1- Help develop innovative business ideas and create projects.

2- Providing technical support to entrepreneurs with an innovative product.

3- Campaigns to raise awareness, training and capacity building to support and encourage entrepreneurs to offer an incubator for the development of their businesses ideas.

4- Training and development in management, marketing, accounting, industrial security training and technical training.

And provide a supportive environment enabling women to work on the crystallization of the idea of their project and planning to develop their work and to receive training and guidance.

- Provide moral support and improve managerial and entrepreneurial capacities.

- Provide guidance and training for incubator projects.

\section{Incubators want to set up projects:}

- Owners of small and micro enterprises.

- The owners of project ideas that show some aspects of creativity.

\section{The methods used to attract customers to the business incubator:}

- Use various channels to advertise for incubators such as advertising in the media.

- Social networks. 
- Awareness sessions in universities and conferences.

- Establish a network of contacts with other institutions concerned with entrepreneurship.

\section{Challenges facing business incubators:}

- Difficult to reach women in rural areas.

- Culture and traditions, freedom of movement and restrictions on women's movement and transmit that affect their ability to attend workshops.

- Women's lack of confidence may abandon its project initiator.

- Women and university graduates prefer to work a fixed salary or government job.

- Male control over the field of technology for technology incubators.

- Difficult to identify the sources of funding for the continuation of its activities in the incubator.

- The difficulty of women are creating more than men project.

- $\quad$ Difficult to identify the most innovative projects.

- Women 's tendency to focus on women 's traditional sectors.

- Work in accordance with the appropriate dates for women entrepreneurs when organizing the training process and other elements of the nursery.

- Identify sources of funding for the continuation of the incubator in its activities.

Incubators programs.

- Assistance in obtaining funding for the project initiator.

- $\quad$ Business advice and guidance by the entrepreneurs of experienced.

- $\quad$ Training on time management - Sales Financial Management.

- $\quad$ Training on marketing through the use of social media.

- $\quad$ Support projects follow-up post-incubator to open all support services.

- $\quad$ Provide workshops and training seminars on entrepreneurship.

- Assistance in registration and access to finance procedures to start the project through training on how to prepare funding proposals. 
- Technical assistance in product development, design, packaging, brand and assist in the marketing of products through national, regional and international trade fairs and markets.

- Provision of services to support technical and social and psychological entrepreneurs.

Services and measures to support services for business development:

- $\quad$ Provide advice, guidance, training and advisory services.

- Assisting in the preparation of feasibility and market studies, action plans and financial proposals and obtain loan studies.

- Dissemination of information and business - related information and support services for small and micro - enterprise programs.

- Training on entrepreneurship for entrepreneurs prefix.

- Training on business managers and owners of small and micro in financial literacy and capacity building in the field of information technology, communications, seminars, workshops, programs, projects.

- $\quad$ Financial management training programs and the development of export markets and improve product quality and packaging.

- Market development, including facilitating participation in trade fairs and exhibitions.

- Help on the development, modernization and production Consulting and design.

- Training and definition of registration of companies, design, product development, market analysis, branding, packaging and services and participation in fairs and markets to display and sell products.

- Provide training programs in marketing, strategy, organization, processes , and information and communication technology, quality management and banking services to help diagnose the needs of the project and to provide advice and support.

- It aims at training to support technical with taking into account the kind consideration is the best guarantee for women and men on the equivalent width of advanced services.

- Create a site or bank information about the ideas new for projects and models for feasibility studies and investment opportunities and legal steps necessary to establish projects and the definition of entrepreneurs export and conditions of procedures and 
provision of information on non - governmental organizations, associations and institutions that support small and micro - enterprises.

\section{Case for Women Entrepreneurs in Southern Egypt Study:}

Business leadership is an alternative way for women to get income as the business pioneers often come from families with low income from their male counterparts and their previous experience in working less and is considered frameworks and tools necessary to support the establishment of projects and development of non - Cafe and facing business majors obstacles and constraints $\mathrm{t} n$ some of the services funding and support for the development of business and banking practices in only s satisfied or lack of group support services for the development of business incubators available and notes that supporting entrepreneurship services business is very limited and notes the urgent need to improve women 's skills to become ready for banks to be able to Presentation Z project of Tha in a convincing manner with the need for the expansion of banks in non - credit services such as training in business, accounting, consulting and financial planning Ast Talaat market and work tools and knowledge in addition to the training programs offered by associations and institutions.

\section{Goals:}

- $\quad$ Case studies of projects owned by women to identify the main obstacles to growth.

- Conduct research and analysis on the economic consequences of the laws that affect the ability of women to entrepreneurship and entrepreneurship and business.

\section{Recommendations:}

- Deploying more awareness about the importance and the role of business development services among business pioneers.

- Make presentations at universities and meetings with NGOs.

- $\quad$ Spreading the culture of microfinance organizations.

- The use of social media in the promotion of business development services. 
- $\quad$ Organize workshops to raise awareness.

\section{Interventions Required:}

- The development of training to improve women's knowledge and the development of business administers products and services and the introduction of technology

- Make use of technology and social media to support women who want more in the management of the effectiveness of projects to start home - based business

- Access services to women in rural areas.

- Capacity-building in the field of development and support of small businesses and entrepreneurs.

- Improved access to information and increase the exchange of experiences through the creation of gatherings for women entrepreneurs to communicate and exchange ideas.

- $\quad$ Provide information on the various types and sources of funding.

- Help women in identifying appropriate sources of funding to transform ideas into projects.

- Women in support of applications for loans through funding and inform them of opportunities to help them in the preparation and funding proposals and help them at the orientation of the banks.

\section{Business Incubators:}

- Promotion of incubators services for projects of women make presentations to communities and women's associations and in local communities.

- Encourage the participation of incubators in training on women's entrepreneurship business information programs to support the development and in business.

- $\quad$ Explore the current financing needs of business incubators projects.

- $\quad$ Processing projects before obtaining Alhadanat services.

- Held regional workshops to discuss the experts in the establishment and operation of incubators. 
- Confirm the sustainability of financing and support services programs for the development of business.

- $\quad$ Promote opportunities to connect with successful projects to learn from experiences.

- Strengthening the role of cooperatives to increase links and links in the exchange of experiences.

- $\quad$ Provide a valid entrepreneurial business environment through the introduction of the culture of business leadership in schools and universities.

- Establishment dedicated to supporting women 's entrepreneurship and business development projects funds.

Implementation of the dialogues and workshops on business leadership with the participation of various segments of society and how to obtain credit and financial services:

- Increasing awareness of bank financing options and terms of getting it.

- To provide legal advisory services during the stages of business registration.

- Innovative loan packages designed specifically for projects led by women.

- To increase awareness of the requirements of bank lending.

- Innovative, such as ensuring security records and programs of credit guarantee systems.

- $\quad$ Care and development, capacity building and training to prepare for the Bank in partnership with banks.

- Increase awareness of the importance of risk account in decision-making processes of banking.

- Dissemination of good practices for international expansion in access to financial products and services to meet the financing needs of women entrepreneurs.

- The development of training programs for financial literacy for women entrepreneurs.

\section{Case Studies Aimed at:}

- Examine the current situation to provide projects for women entrepreneurs support services. 
- Examine the current situation of women's participation in business incubators

Challenges that face women entrepreneurs:

Facing the development of women 's leadership to work many of the challenges include cultural and social barriers and access to finance and lack of knowledge and skills of business, cultural and social barriers.

- Women lack the ability to establish a project 's leadership and his administration because of poor culture of business entrepreneurship among women and in addition to the lack of family support at the outset in addition to economic and various obstacles of to reduce the ability of women to private mobility in rural areas, preventing them from the project in the work outside the home and access to remote markets from nearby local areas.

\section{Access to finance:}

Women entrepreneurs are having difficulty in getting private financing from banks because of women 's lack of property that could be used to guarantee loans and the lack of institutions to finance smaller.

- The provision of information and assistance in the knowledge of the sources of funding

\section{Lack of skills:}

- The urgent need to encourage and assist business entrepreneurs and graduates to start new projects

- Women 's lack of skills in financial management, computers, marketing and lack of knowledge of procedures and legal know - how, as well as in organizing and planning business, which affects the creation and growth of its business continuity and for those wishing to start and develop projects that relate.

\section{Lack of programs: -}

- Women need more training and technical assistance areas of leadership and access to finance and training on technical issues, business management and technology

- The provision of training, vocational and specialized skills upgrading and appreciation of the support technical in the administrative, financial and marketing areas 
- Inspect the registration of operations for the business sector, the official, pushing women 's projects in rural areas to the informal sector and the lack of women in rural areas to know how operations license, which is usually complex in addition to the difficulty of recording projects that operate from homes where there are restrictions for access projects working home making it difficult to establish a record project and is licensed based home.

- Improve the climate for women entrepreneurs.

- Procedures and measures of climate and work environment for women entrepreneurs to improve.

- Raising awareness of the role of women in entrepreneurship and its importance in creating added value and competitiveness in the economy and stimulate the spirit of entrepreneurship among women more effectively.

- Exemption from social duties and taxes to encourage the largest number of women to carry out project activities.

- Work to facilitate the registration of projects and increased flexibility in working procedures.

- Teaching entrepreneurship in schools and universities.

- Provide incubators to support women 's projects.

- Enhance opportunities for women entrepreneurs for funding.

\section{Propose the following measures: -}

- $\quad$ The development of products / special for women financing tools.

- $\quad$ Establish special sections for women in microfinance institutions.

- Take the necessary measures to McCain women's access to finance, such as loan guarantees - capital investment - Training Financial - Coaching and guidance in order to facilitate the process of obtaining funding.

\section{The measures of the General:}

Organization of special programs for women entrepreneurs to promote self - confidence as entrepreneurs and increase the capacity to own project management in order to: - 
- The establishment of workshops and seminars to guide the work, training, and the definition of tax law and procedures.

- Assist in the preparation of feasibility, business plans, product design and development studies.

- $\quad$ Training on startup and training administrative Advanced.

- $\quad$ Provide business advice.

- $\quad$ Training on advanced skills in management and entrepreneurship.

- $\quad$ Training on how to get funding.

- Training workshops to support the training in post - establishing the project.

- Support for women entrepreneurs in the innovative stage after the creation of their projects in order to support energy pioneers of administrative work and increase their ability to manage daily business in their projects.

- Training on marketing, sales, organization, management and personal development and negotiation skills accounting, tax and information technology.

- $\quad$ Training on the basis of productivity and quality.

- Training on the formulation of proposals bankable and how to present to banks.

- Training on how to deal with banks.

- $\quad$ Training on gender equality in employment and small businesses.

- The supply of women seeking work skills involved and project management skills to increase their access to employment opportunities.

- Assessment of local and international marketing opportunities and assistance in the promotion of marketing services for owners of small businesses

- Preparation of business plan competitions on the Internet networks for women entrepreneurs to encourage entrepreneurs to start and develop their own businesses through training and guidance by giving the winners of opportunities for funding for projects

- Training to assist in the development of business plans and enable business progress to the next level to encourage entrepreneurship and build the capacity of women entrepreneurs 
Challenges facing the provision of support services for the development of business for women entrepreneurs:

- Support business development offers not targeted enough new projects prefix for young people and women may not be available.

- Materials and training resources are available in English, which limits its usefulness to the best educated among the entrepreneurial community groups.

- The number of organizations capable of meeting the demand for support services for the development of projects less than required, especially in rural areas.

- Women do not Icdjan enough to start a business and need to be convinced that entrepreneurship is a viable and promising option for them.

- For cultural reasons women are reluctant to risk in addition to their self - weak in the ability to start and run a project

- Vulnerability to conflicts over how to balance family responsibilities and activity, which requires the intensification of the pioneering efforts to promote the integration of women in the labor force and creating a higher level of awareness about the potential of entrepreneurship as an option for women Magdi.

The required efforts to improve support for the development of women entrepreneurs projects:

- Increase efforts to improve the training provided in the field of management for women entrepreneurs

- Organize specialized workshops to deal with the specific problems faced by projects

- Use of social media to extend services to young people

Additional actions required to meet the needs of women entrepreneurs from effective services to support business development;

- Improve the sustainability of programs and funding

- Considered sustainable funding for support programs for business development is essential to ensure the provision of services and must therefore adopt a national policy to ensure the sustainability of support for business development services. 


\section{Knowledge transfer and skills development:}

- It is committed to the urgent need for more technical support for capacity building in the areas of entrepreneurship and business development and capacity building for trainers in providing support for the development of the largest business group of pioneers and businesswomen

- Make short modules to meet the needs of entrepreneurship at least women's instructions

- Take more effective methods to reach women entrepreneurs

- A database for women wishing to start a business project through partnership with associations and civil society institutions in order to achieve better communication with women entrepreneurs prepare

- Raise awareness among women entrepreneurs

- Entrepreneurs need more information and awareness regarding support services and evaluated by holding workshops to raise awareness of the importance of entrepreneurship and small businesses in the presence of pioneers of business achievers.

- Take advantage of social media to promote and support the BDS

- A special design for training and support services business fits the needs of women entrepreneurs

- A study and compilation of data on self - employment for women and entrepreneurship from home.

- Training for women entrepreneurs design in shorter periods and at lower cost.

- The need to introduce gender considerations in training materials

- Focus on capacity-building to improve entrepreneurs, business management and increase knowledge of business management and product development and the introduction of ecommerce in business operations

- Training to learn the best practices in the development of small enterprises

- Training on the transition from the informal to the formal sector

\section{Financing issues:}


- Opportunities for women to consider financing through loans or equity investment in less than men as women entrepreneurs come from shorter than those that come from men social segments and for reasons related to the culture of the community

- $\quad$ Asymmetry of information between banks and entrepreneurs hindering bank lending for business operations

- $\quad$ Lack of collateral to meet the banks' requirements for bank loans

- Lack of experience in the progress of the lenders and banks for projects that they can accept

- Although it advertised through surveys that were with banks, but the interest in the volume of loans granted to small and micro-enterprises, especially for women of banks surveyed represents only a simple and small part of the investment activity of banks

- $\quad$ Financial products provided to women for banks short - term loans - medium term long - term.

- $\quad$ Projects that have received funding from the banks surveyed are projects in cities and villages is not.

- Banks surveyed confirmed that their policies and procedures for gender-neutral lending is not discriminatory

- The survey proved that the conditions imposed by banks on collateral and credit history that the experience in projects and strategies when making bank lending decision does not do justice to women 's projects.

- The survey proved that the strict regulations for risk management increases the feet of banks to risk in this new market.

- All of the banks surveyed indicated the importance of the evidence on the ability to pay and the necessity of having a history of credit and guarantees which is one of the most important criteria that qualify for loans.

- The survey proved that the women's credit file will be weaker than the man

- The survey proved that women do not have sufficient experience with regard to their ability to explain Wafi to its case.

- The survey has shown a lack of administrative and financial skills on the submission of plans for projects to clarify its strategy in the short and medium term as well as tracking 
financial records, such as budgets, accounting and audits.

- The survey proved that the banks prefer to avoid risk so be strict with the requirements of small and medium enterprises.

- The study of banks not to provide programs specially tailored or personalized services, or product designed specifically targeted projects led by women explained.

- Banks recognized that the services, products and programs focusing on the financing of projects led by women are still incomplete.

- It recognized that banks must identify more needs and troubles women entrepreneurs in obtaining finance and in business administration in preparation for the launch of financing and advisory services dedicated to women entrepreneurs.

- Banks also show little awareness of the issue stemming from the culture faced by women entrepreneurs such as their mobility and high demand for restrictions and time limits, which may more than their ability to obtain funding.

- The study demonstrated that helping to raise awareness of banks products, processes and services that reduce the prevailing progress process to get a loan seems too complex culture.

- The study demonstrated that reducing the funding gap between the pioneers and entrepreneurs and banks by focusing on the reform of bank financing for small and mediumsized enterprises agenda and promote innovation in the field of microfinance

- Banks should take measures to enhance transparency and improve the exchange of information and awareness - raising efforts aimed to improve financial support for projects Services

- Must develop the skills to prepare to deal with the banks and what you expect to meet and master the ability to view projects in a convincing manner

A practical guide to help identify funding sources

\section{Objectives:}

- Capacity-building in obtaining funding for projects from banks

- Review of financing options and sources 


\section{Funding sources:}

\section{1- Contribution of personal funds}

Funding is through the investment of personal funds more the amount of the contribution has increased the greater the confidence and the new partners and will contribute to the financing or start some investment costs. Which does not give bank loans.

- The personal financial contribution to the establishment of a commercial activity or project acquisition represents the total capital invested by the project owner instead of borrowed capital if the project owner can provide part of the funds, the project will be more solid and continuity.

\section{2- Microcredit}

Finance aims Alosgralamt_khass to help entrepreneurs to start their business or expansion and microcredit is a small loan for a maximum period of five years granted by non-bank financial institutions with a view to financing the establishment of a new project or develop an existing project for the selection of the system should work comprehensive comparison of interest rates to credit smaller

This can be used loan the repayable to obtain the necessary to start the project of basic materials and engage in the field of entrepreneurship.

\section{Bank loan:}

- The Bank lends the amount needed for the establishment of a project or the development of the company in exchange for payment in installments spread over a period of time plus a fixed or variable compensation in the form of interest where it saves external resources while avoiding interference by third parties in the management of the project.

- The loan granted by the bank on the quality of the project and the amount will depend on the guarantees that can be provided where banks require personal guarantee from the owner of the acceptance of the mortgage on his home or personal use of his property as collateral. The bank guarantees at the request include deposit transferred-personal property - guarantee - mortgage - bills - data to prove where the company's investment exceeds the value of collateral required amount borrowed (120\% to 150 of the amount ) to 
reduce the risk ratios.

\section{Short - term advances:}

Credit facilities and withdrawals unauthorized overdraft is considered a form of short - term credit and for use in short periods of the pre - bank by writing to the terms of use in terms of duration and amount of interest rate and determine the duration of use with the official in the bank and is determined by the amount authorized in Alontmaiah facilities or in the contract overdraft and is determined according to the operational requirements of the project, where it terminates within the financial terms of the contract signed between the project owner and the bank

- Keep track of credit facilities and overdraft great flexibility in cash management fluid and this type of credit can help in dealing with temporary disability, which may face the entrepreneur and is covered by the company's employees' salaries.

- And the entrepreneur to provide bank interest on the basis of the total amount used and its term of use interest is the collection of direct deduction from the company's account I have Minot discount

- Discount is a form of specialized short-term credit can be used by the project owner if they have sold goods to the customer and granted deadline for payment, where the entrepreneur issued a promissory note exchangeable at maturity

- Just the client for this bill signed by him this approval means approval is the final deadline for payment if the project owner needs immediate funding could ask her bank to lend the same amount in the calculation of the deduction many advantages:

- Immediate lending to the amount due to the customer, which achieves a positive cash flow than other traditional methods such as short - term financing-cash facilities-allow overdrafts.

- Customers indebtedness does not appear in the general budget of the partners

- Allow a discount line agreement between the bank and entrepreneurs transfer fee includes bills discounted fee for each bond trading was his opponent in the same bank discount and interest rates are calculated in advance the amount of commercial bonds issued debit and credit amounts to a period of 


\section{Investment financing:}

The use of investment loans to finance investment, non - commercial - and worth the loan investment generally repayable in monthly installments or quarterly each batch is made up of part of the principal and interest, and insurance for the risk of death or disability vary for the lender depending on the type of item to be converted, including its benefits investment loans on the ability to get on the financing of $100 \%$ to avoid the use of personal funds and the possibility of choosing the repayment period and the possibility of repayment and the possibility of obtaining tax cuts to declare the interest on these loans under financial flows from the income statement

Those wishing to obtain a loan from the bank to participate in the life of equipment necessary for project development and should include a form and adequate statement of law , price or primary equipment - another balance sheet and income statement - financial plan

\section{Lease of property and equipment:}

In the case of lease, the Bank or one of its specialized companies to buy property or equipment on behalf of entrepreneurs and lease them throughout the period of the agreement , which usually be between 8-15 properties and from 1-5 years for movable property where the Bank to take action in terms of evaluating the quality of the value of the property required lease and called monthly premiums or annual rent a quarter and paid in advance that the entrepreneurs to pay a deposit as a guarantee commensurate value with the cash value of the asset in the last term of the lease and deposit guarantee or pay increase in the first month rent lowers the monthly lease payments

\section{Commercial Mortgage: -}

Mortgage business is a long - term loan from 8-15 years are paid according to a schedule determined from the beginning and made up the mortgage payments of part of the borrowed capital plus the interest accrued on the paid -up capital, and added that the insurance was found to life or disability is usually the bank required to use the property funded by the loan as collateral, for example, as collateral can be of interest calculated at a fixed price from the beginning to the loan and in this case, all payments are the same size and can be 
of interest calculated at a variable rate or a table and have some loans that have a price variable or scheduler determines them a maximum and a minimum in order to protect the borrower from any fluctuations in the interest rate pain retroactive

\section{Guidelines for pioneers and entrepreneurs:}

1- Double contacts with banks and financial institutions

2- Compare prices offered by different institutions and the terms of duration and payment

3- Negotiate and obtain the skills of appropriate interest

4- Be patient and lack of frustration in negotiating with banks

5- It is characterized by transparency in the administrative obligations of proof of good faith with the bank

6- The organization of the ongoing financial contacts with the Bank

7- Commitment to achieve financial balance and profitability of banking and merit

8- The development of mutual trust with banks to facilitate access to financing in the end

9. Demonstrate that the project is required to meet real needs

10- Use of simple phrases to explain the projects in a manner clear and simple language increases the chance of success

\section{Financial Liquidity Management Tools}

\section{First: employing capital}

The employment of capital through the development of a formula for regular creativity so easy to predict expenditures and distributed to time periods through the formation of a savings reserve account both for the management of financial liquidity or unexpected expenses or to meet any emergency event or to obtain a return on the amounts are not needed to it immediately or to build a personal financial head.

\section{Second: The deadline for payment}

Good repayment schedules lead to reduce the urgent need for liquidity and the level needed 
to finance the management is done by increasing the ability to negotiate with the supplier sense to limit the number of suppliers for each item and by reducing the number of suppliers to enable the contractor to increase the required of each resource size and becomes better to negotiate a position deadline for payment as any extension of the deadline payment opportunity for the client or by the supplier where by the entrepreneurs to extend the deadline for repayment of the client have been funding a Anaajath of cash and vice versa , and when the supplier determine payment deadline, which finances the needs of entrepreneurs and entrepreneurs of repayment.

\section{Commercial discount:}

Commercial discount is the commercial transaction the customer can pay the supplier bill in cash and within a short period of time rather than a waiting time payment deadline in exchange for a discount by a simple determined by the supplier and to avoid facing a lack of liquidity problems through project funds support to re - enter some of the profits, allowing support The project financially through the formation of building sufficient reserves to serve as a bank that is being dealt with, which in turn will accompany the project when the project is to develop a strong indicator.

\section{Buy debt:}

Buying debt is a method of financing accounts receivable methods through the sale of debt owed to the client 's specialized financial institution which places the burden of securing the collection of debt to the financial institution and the purchase of debt is the method of funding is available for any type of business in any sector, regardless of its size.

Among the benefits of the possibility of collection directly when the invoice was issued, rather than waiting for the date of payment in addition to the mandated purchase of debt institution is not preoccupied with the pioneers and entrepreneurs to pay the bill, where the financial institution is the task of collection where the agreement between the financial institution and entrepreneurs through risk and detailed data for billing and dates of payment Rating available to the customer where the value of the institution to pay the bill for entrepreneurs after deducting costs and amount to meet potential difficulties where these financial institutions provide insurance risk insurance for its customers who want to protect themselves from the customer service at the default risk Payment 


\section{Financing of foreign trade:}

In a favorable economic environment it has increased international trade transactions without corresponding change in insurance payments that were made simple transfers, where the use of documentary credit and the length of export support.

\section{Documentary credit:}

Payment depends on the documents and not on the actual goods or services provided as it guarantees payment for transactions under the wage source process from importing a foreign financial institution agrees to pay a specified amount to the source in a given time frame against documents set out in accordance with the letter of credit.

There are many ways to pay for letters of credit payable immediately and the payment is made to provide specific documents for letters of credit payable at a specified date payment is made after a certain period of time after delivery of documents

\section{Supply chain financing:}

Is providing funding through the supply chain financing structures and is intrinsically linked to the financing of the working capital of the companies is part of theassets that facilitate access to different types of loans according to the size, type and availability of the assets of the borrower where they are through thefinancing bank to carry out payment to the customer when you buy products or financing solutions services without waiting to pay the bill and enables the supplier to get a full refund after a few days of receipt of goods or services in exchange for payment of fees calculated on the relative value of the debt, allowing entrepreneurs a longer time frame to pay the bill for the duration of the bank up to 40 days

\section{Export credit:}

This tool provides credit rates guaranteed by the government less than those shown in the banking market, where countries grant export credits through thebodies of credit issued by the public support for the export of programs to help local exporters to compete with other countries in foreign markets and the Commission export credit to provide credit to foreign 
buyers either directly or through private financial institutions providing them with funding or security operations.

\section{Refinancing of foreign currency:}

- Is considered a short - term tool is widespread among importers and allow banks to negotiate with the agents responsible for the lines of credit to finance imports this tool allows importing company to postpone the payment of the value of imports, with a minimum of 30 days and may reach 360 days and the equivalent of the amount of credit the value of the import process in addition to the interest

- The company imported Bank to take action for the resource payment according to the terms of the contract and at the same time, the client gives deadline for repayment of up to 360 days.

- Pre - financing for the export of foreign currency this cash - term credit short dedicated local currency to customers co - exporters to do locally with funding necessary to meet the export of the production order cycle for the purchase of raw materials, supplies and operational requirements and is intended primarily import-export companies and small and medium - sized enterprises and this type of credit the maximum period of a year one renewable

- Mobilization of foreign currency debts

- This credit cash in hard currency followed by the process of mobilizing foreign currency debt is granted to the source when the source has provided Timeouts payment to foreign buyers.

- The goal is to collect foreign assets in foreign currencies in order to rebuild the company's cash flow until the receipt invoices and the proceeds are these packing by agreeing to a special line of credit up to $100 \%$ of the value of debt and enable the compilation of receivables in foreign currency.

\section{References:}

- $\quad$ Adamson, Glenn. The Invention of Craft. $1^{\text {st }}$ ed. London: A \& C Black Publishers, 2012.

- Auther, Elissa. String, Felt, Thread: The Hierarchy of Art and Craft in American Art. $1^{\text {st }}$ ed. Minneapolis: University of Minnesota Press, 2010. 
- $\quad$ Bratich, Jack Z., and Heidi M. Brush. "Fabricating Activism: Craft-Work, Popular Culture, Gender." Utopian Studies 22.2 (2011): 233-260. Web. 1 Jan. 2017.

- $\quad$ Broecke, Lara, and Cennino Cennini. Cennino Cennini's Il Libro Dell'arte. $1^{\text {st }}$ ed. London: Archetype Publications, 2015.

- $\quad$ Bryant, Julius, and Susan Weber. John Lockwood Kipling: Art and Crafts in the Punjab and London. 1st ed. New Haven: Yale University Press, 2017.

- $\quad$ Buszek, Maria Elena. ""Labor Is My Medium": Some Pespective (S) On Contemporary Craft." Archives of American Art Journal 50.3/4 (2011): 66-75.

- Charny, Daniel. Power of Making: The Importance of Being Skilled. $1^{\text {st }}$ ed. London: Victoria \& Albert Museum, 2011.

- $\quad$ Coatts, Margot. Pioneers of Modern Craft. $1^{\text {st }}$ ed. Manchester: Manchester University Press, 1997.

- $\quad$ Cooke Jr., Edward S. "Modern Craft and the American Experience." American Art 21.1 (2007): 2-9.

- $\quad$ Dormer, Peter. "The Language and Practical Philosophy of Craft." The Culture of Craft. Peter Dormer. $1^{\text {st }}$ ed. Manchester: Manchester University Press, 1997. 219-230.

- Frayling, Christopher. On Craftmanship: Towards A New Bauhaus. $1^{\text {st }}$ ed. London: Oberon Books, 2011.

- Greenhalgh, Paul. "Introduction: Craft in a Changing World." The Persistence of Craft. Paul Greenhalgh. $1^{\text {st }}$ ed. London: A\&C Black, 2002. 1-17.

- $\quad$ Hamilton, Laura. Radical Craft: Alternative Ways of Making. $1^{\text {st }}$ ed. Birmingham: Craftspace, 2016.

- Harrod, Tanya. The Crafts in Britain in the 20Th Century. $1^{\text {st }}$ ed. New Haven: Yale University Press, 1999.

- $\quad$ Pastor, Julia. "The Materiality of Tapestry in the Digital Age." The Journal of Modern Craft 9.3 (2016): 289-311.

- $\quad$ Portisch, Anna Odland. "The Craft of Skilful Learning: Kazakh Women's Everyday Craft Practices in Western Mongolia." Journal of the Royal Anthropological Institute 16 (2010): S62-S79.

Received: July 26, 2020

Accepted: August 20, 2020 